\title{
ANALISA DAN PERBANDINGAN BUKTI FORENSIK APLIKASI MEDIA SOSIAL FACEBOOK DAN TWITTER PADA SMARTPHONE ANDROID
}

\author{
Wisnu Ari Mukti, Siti Ummi Masruroh, Dewi Khairani \\ Jurusan Teknik Informatika UIN Syarif Hidayatullah Jakarta \\ Jl.Ir. H. Juanda No.95 Ciputat 15412 Jakarta-Indonesia \\ wisnuarimukti@gmail.com
}

\begin{abstract}
ABSTRAK
Perkembangan teknologi internet dan smartphone yang semakin pesat diikuti pula oleh meningkatnya pengguna media sosial yang mengakses menggunakan smartphone khususnya Android. Salah satu permasalahan yang tak luput dari media sosial adalah tindak kejahatan dunia maya yang memanfaatkan media sosial, karena pada dasarnya tidak ada kejahatan yang tidak meninggalkan jejak. Penelitian ini dilakukan untuk menemukan dan membandingkan bukti-bukti forensik tersebut pada aplikasi media sosial Facebook dan Twitter yang diakses pada smartphone Android. Facebook dan Twitter dipilih karena memiliki beberapa fitur yang mirip. Pada penelitian ini, metode simulasi digunakan dalam penelitian dengan menjalankan 11 skenario di antaranya adalah pengembalian file yang dihapus, pencarian bukti forensik berupa nama akun, lokasi, nomor telpon, tanggal lahir, photo profile, cover photo, posting berupa teks, posting berupa gambar, isi private message berupa teks dan isi private message berupa gambar. Hasil dari penelitian ini menunjukkan bahwa semua bukti forensik pada aplikasi media sosial Facebook berhasil ditemukan semua. Sedangkan pada aplikasi media sosial Twitter hanya berhasil ditemukan berupa nama akun, data lokasi, photo profile, cover photo, posting berupa teks dan posting berupa gambar.
\end{abstract}

Kata kunci: Digital Forensik, Bukti Forensik, Smartphone, Facebook, Twitter

\begin{abstract}
The development of internet technology and smartphones are increasing rapidly followed by increasing social media users who access using a smartphone, especially Android. One of the problems that did not escape from social media is cybercrime acts that utilize social media, because basically no crime that does not leave a trace. This study was conducted to find and compare the forensic evidence on Facebook and Twitter social media applications which were accessed on Android smartphones. Facebook and Twitter were selected for having some similar features. In this study, the simulation method used in the research by running 11 scenarios such as return of deleted files, search for forensic evidence in the form of account name, location, phone number, birth date, photo profile, photo cover, text posts, image posts, private message content in text form and private message content in picture form. The results of this study indicate that all forensic evidences on Facebook social media application can be found. While in the Twitter social media application only managed to found in the account name, location data, photo profile, photo cover, text posts and image posts.
\end{abstract}

Keywords: Digital Forensics, Forensic Evidence, Smartphone, Facebook, Twitter

DOI: $10.15408 /$ jti.v10i1.6820 


\section{PENDAHULUAN}

Perkembangan teknologi semakin berkembang dengan pesat dan salah satunya adalah smartphone. Telepon genggam pada masa kini sudah tidak sekedar digunakan untuk melakukan panggilan atau berkirim pesan singkat. Telepon genggam pada masa kini telah dilengkapi dengan sistem operasi sehingga dapat melakukan beberapa fungsi layaknya personal computer, salah satunya adalah mengakses internet. Pada Januari 2016 pengguna smartphone mengakses internet dengan platform berbasis Android sebanyak $66 \%$, Apple iOS 19\% dan platform lainnya sebanyak $15 \%[6]$.

Perkembangan teknologi smartphone yang memudahkan orang-orang dalam mengakses internet diiringi juga dengan banyaknya penggunaan media sosial. Jumlah pengguna aktif media sosial diseluruh dunia mencapai 2,31 Triliun, yang artinya setara dengan 31\% dari total populasi penduduk dunia[]. Pada awalnya media sosial hanya terbatas diakses dengan menggunakan personal computer (PC). Pada Januari 2016 pengguna media sosial yang mengakses media sosial dengan menggunakan smartphone sebanyak 1,97 Triliun atau setara dengan $27 \%$ dari total populasi penduduk bumi[6]. Pada Juni 2016 media sosial dengan pengguna paling banyak adalah Facebook 1,65 Milyar pengguna, Qzone 650 Juta pengguna, Instagram 500 Juta pengguna, Twitter 310 Juta [24].

Namun perkembangan media sosial dimanfaatkan oleh sebagian orang untuk melakukan tindak kejahatan. Tidak sedikit tindak kejahatan dilakukan menggunakan media sosial yang diakses melalui smartphone. Kejatahan yang bisa disebabkan oleh media sosial diantaranya penculikan, penipuan, pemerasan, cyberbully dan lainnya. Kejahatan pada media sosial Facebook dan Twitter meningkat sebanyak $780 \%$ selama 4 tahun dari tahun 2008 (556 kasus) sampai tahun 2012 (4908) kasus[3].

Berdasarkan pernyataan di atas, penulis melakukan penelitian dengan judul "Analisa dan Pencarian Bukti Forensik pada Aplikasi Media Sosial Facebook dan Twitter pada Smartphone Android".

\section{METODOLOGI PENELITIAN}

Penelitian ini menggunakan metode simulasi, metode simulasi terdiri dari beberapa tahap-tahap seperti berikut:

\section{II.1 Problem Simulation}

Permasalahan utama dengan meningkatnya akses media sosial dengan menggunakan smartphone adalah maraknya tindak kejahatan yang dilakukan oleh pihak yang tidak bertanggung jawab dengan memanfaatkan media sosial yang diakses melalui smartphone. Pada tahun 2013, 81\% kejahatan internet (cyber crime) melibatkan media sosial. 39\% pengguna media sosial telah menjadi korban penipuan, hacking dan fake link. Dan 33\% semua kejahatan seks pada dunia maya dipicu melalui situs jejaring sosial[17].

Dengan tingginya jumlah pengguna yang mengakses media sosial dengan menggunakan smartphone dan tingginya angka kriminalitas pada media sosial, diperlukan upaya pencarian bukti forensik dan analisa untuk membantu pihak berwenang dalam menyelidiki kasus kejahatan yang melibatkan media sosial dan smartphone, karena pada dasarnya dalam dunia kriminal dikenal istilah "tidak ada kejahatan yang tidak meninggalkan jejak"[4]. Bukti forensik pada smartphone menjadi tambang emas bagi penyidik forensik karena sifat personalias dari kepemilikan smartphone tersebut [12]. Data yang diambil dari perangkat smartphone dengan sendirinya dapat dijadikan bukti. Bukti-bukti ini dapat menjadi landasan ketika menyelediki suatu perkara oleh lembaga penegak hukum [22].

Berdasarkan pemaparan di atas, penulis akan melakukan analisis dan pencarian bukti forensik terhadap aplikasi media sosial Facebook dan Twitter yang diakses pada smartphone Android. Penelitian tersebut bertujuan untuk menemukan dan membandingkan bukti forensik yang ditemukan pada smartphone yang digunakan untuk mengakses media sosial. Adapun artikel ini merupakan hasil orisinil dari penelitian yang penulis lakukan.

\section{II.2 Conceptual Model}

Dalam penelitian ini, tahap membuat konsep model merupakan tahap dilakukannya penggambaran dari input, proses dan output yang dihasilkan. Gambaran arsitektur proses pencarian bukti forensik pada aplikasi media sosial Facebook dan Twitter. 


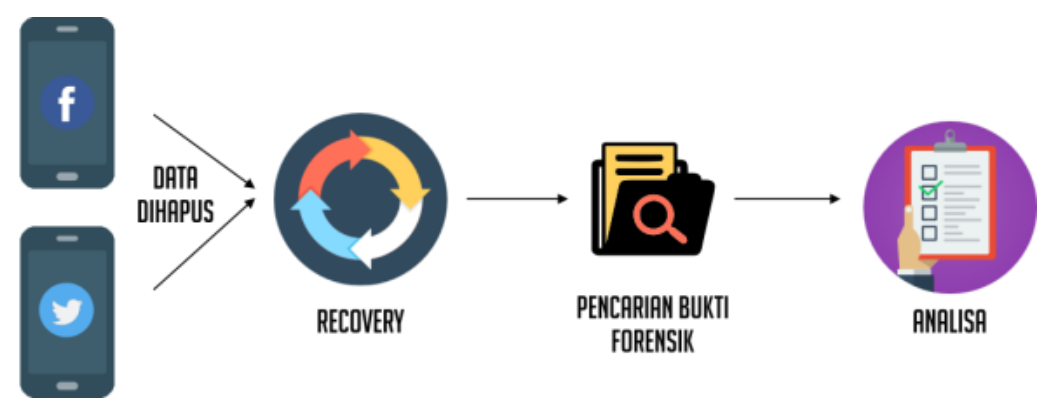

Gambar 1. Arsitektur simulasi pencarian dan analisa bukti forensik

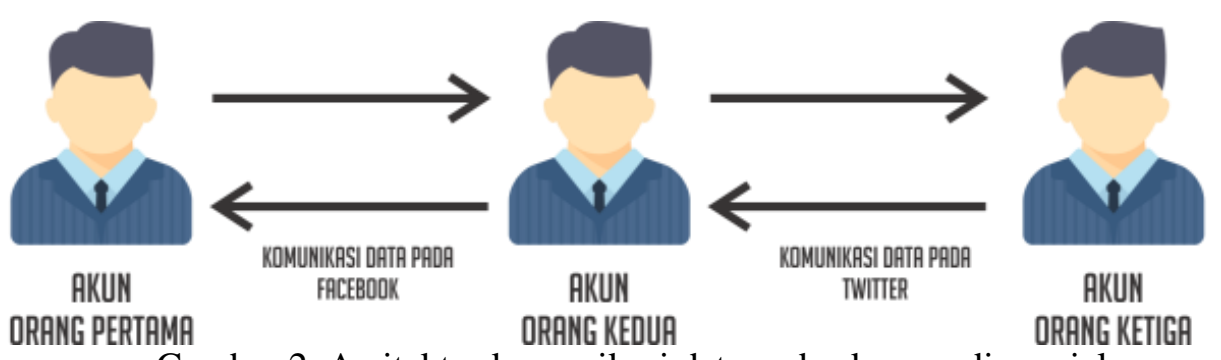

Gambar 2. Arsitektur komunikasi data pada akun media sosial

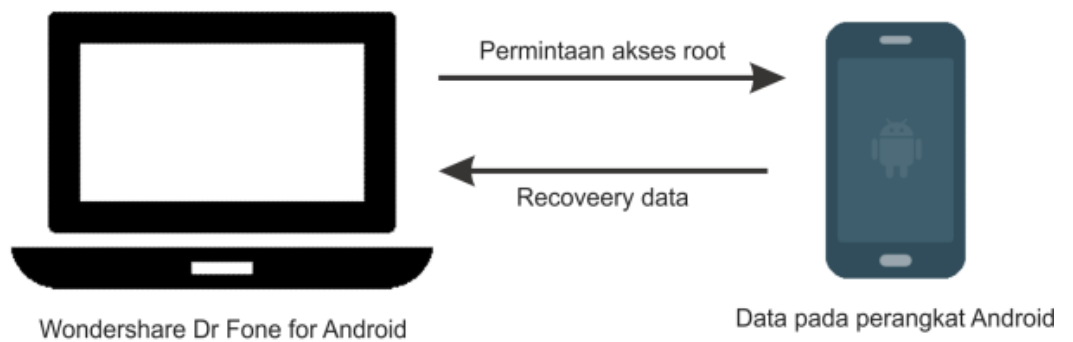

Gambar 3. Proses recovery data

Gambar 1 menggambarkan asrsitektur dalam pencarian dan analisa bukti forensik pada penelitian kali ini. Perbedaan hanya terdapat pada aplikasi media sosial yang digunakan. Sedangkan pada gambar 2 menggambarkan komunikasi data pada akun media sosial sebelum dilakukan pencarian bukti forensik pada aplikasi media sosial tersebut. Selain itu penulis melakukan penghapusan data pada aplikasi media sosial dengan asumsi bahwa data tersebut dihapus oleh pelaku tindak kriminal untuk menghilangkan jejak kejahatan. Pada gambar 3 menggambarkan proses recovery data menggunakan aplikasi Wondershare Dr Fone for Android. Aplikasi tersebut meminta akses root pada perangkat Android dan data hasil recovery akan disimpan pada perangkat komputer. Komponen pada tiap-tiap arsitektur adalah sebagai berikut:
1. Smartphone

Smartphone digunakan sebagai platform untuk mengakses media sosial Facebook dan Twitter. Smartphone yang digunakan oleh penulis adalah smartphone bermerek Xiaomi Redmi 2 berbasis Android Versi 4.4.4 (Kitkat) yang telah mendapat akses root.

2. Aplikasi Media Sosial

Aplikasi media sosial yang diinstall pada smartphone adalah Facebook Apps versi 77.0.0.20.66, Facebook Messenger versi 70.0.0.12.68 dan Twitter Apps versi 5.109.0.

3. Aplikasi Recovery file

Aplikasi recovery digunakan untuk mengembalikan data yang sebelumnya telah dihapus untuk menghilangkan bukti forensik. Aplikasi yang penulis gunakan adalah Wondershare Dr. Fone for Android. Aplikasi ini akan meminta 
akses root untuk dapat melakukan recovery pada smartphone.

4. Aplikasi Database browser

Database Tool digunakan untuk melakukan analisa dan pencarian terhadap bukti forensik yang tersimpan pada database yang sebelumnya berhasil dikembalikan dengan menggunakan aplikasi recovery. Aplikasi database yang digunakan adalah SQLite Manager dan DB Browser for SQLite.

5. Validasi

Akun palsu digunakan dalam pencarian bukti forensik. Sebelum dilakukan pencarian bukti forensik terlebih dahulu dilakukan komunikasi data antara akun media sosial tersebut. Berdasarkan gambar 2 akun orang pertama akan melakukan komunikasi data dengan akun orang kedua melalui Facebook dimana posisi orang pertama adalah pelaku kejahatan dan orang kedua adalah korban. Sedangkan akun orang ketiga akan melakukan komunikasi data dengan akun orang kedua melalui Twitter dimana posisi orang ketiga adalah pelaku kejahatan dan orang kedua adalah korban.

6. Bukti Forensik yang ditemukan

Setelah pencarian bukti forensik pada database telah selesai, maka bukti forensik pada aplikasi media sosial Facebook dan Twitter akan saling dibandingkan sesuai dengan skenario yang dilakukan.

\section{II.3 Input/Output Data}

Pada tahap ini merupakan proses penentuan input yang akan digunakan dalam penelitian. Input pada penelitian yang akan digunakan pada aplikasi media sosial Facebook dan Twitter adalah sama yang berupa teks dan gambar diantaranya adalah: Nama akun, Lokasi, Nomor telepon, Tanggal lahir, Photo profile, Cover photo, posting berupa teks, posting berupa gambar, isi private message berupa teks, isi private message berupa gambar. Semua data yang di-input adalah sama.
Tabel 1. Bukti forensik yang akan dicari

\begin{tabular}{lll}
\hline $\begin{array}{l}\text { Data yang di- } \\
\text { input }\end{array}$ & $\begin{array}{c}\text { Bentuk } \\
\text { data }\end{array}$ & $\begin{array}{l}\text { Isi teks dan file } \\
\text { gambar }\end{array}$ \\
\hline Nama akun & Teks & Pratama Pertama \\
\hline Lokasi & Teks & $\begin{array}{l}\text { Semarang, } \\
\text { Indonesia }\end{array}$ \\
\hline $\begin{array}{l}\text { Nomor } \\
\text { telepon }\end{array}$ & Teks & +6285776267290 \\
\hline Tanggal lahir & Teks & 1 Januari 1991 \\
\hline Photo profile & Gambar & Profile.jpg \\
\hline $\begin{array}{l}\text { Cover Photo } \\
\text { Posting } \\
\text { berupa teks }\end{array}$ & Gambar & Siput.jpg \\
\hline $\begin{array}{l}\text { Posting } \\
\text { berupa } \\
\text { gambar }\end{array}$ & Gambar & Test 123 \\
\hline $\begin{array}{l}\text { Isi private } \\
\text { message } \\
\text { berupa teks }\end{array}$ & Teks & $\begin{array}{l}\text { Percakapan } \\
\text { pihak terkait jual } \\
\text { beli handphone }\end{array}$ \\
\hline $\begin{array}{l}\text { Isi private } \\
\text { message } \\
\text { berupa } \\
\text { gambar }\end{array}$ & Gambar & Nokia3310.jpg \\
\hline
\end{tabular}

\section{II.4 Modelling}

Pembuatan skenario-skenario yang akan digunakan untuk proses simulasi. Pada penelitian ini terdapat 11 skenario, masingmasing skenario dilakukan 2 kali percobaan. Skenario tersebut adalah sebagai berikut:

Skenario 1 adalah melakukan recovery data pada aplikasi Facebook dan Twitter yang sebelumnya telah dihapus pada smartphone. Selanjutnya skenario 2-11 adalah tahap pencarian bukti forensik terhadap aplikasi Facebook dan Twitter. Bukti forensik yang dicari adalah sebagai berikut: Nama akun, Lokasi, Nomor telepon, Tanggal lahir, Photo profile, Cover photo, posting berupa teks, posting berupa gambar, isi private message berupa teks, isi private message berupa gambar.

\section{II.5 Simulation}

Proses simulasi akan dijalankan menggunakan skenario yang telah ditentukan pada tahap sebelumnya pada tahap ini. Selain itu, pengujian dilakukan sesuai dengan parameter yang telah ditentukan juga pada tahap sebelumnya.

Sebelum simulasi dijalankan dilakukan beberapa persiapan seperti rooting perangkat Android, pembuatan akun palsu, pemasangan 
aplikasi recovery file dan pemasangan aplikasi database browser.

\section{II.6 Verification and Validation}

Verifikasi dan validasi dari tahap-tahap sebelumnya dilakukan pada tahap ini. Jika terjadi kesalahan pada masing-masing tahap metode simulasi maka akan dilakukan koreksi atau perbaikan pada tahap tersebut.Verifikasi dilakukan dengan menguji apakah proses root pada smartphone berhasil dilakukan atau tidak dan menguji apakah aplikasi recovery file (Wondershare Dr. Fone for Android) dan database browser (SQLite Manager dan DB Browser for SQLite) dapat berjalan. Sedangkan validasi dilakukan dengan dengan cara mengecek kembali apakah akses root pada smartphone berjalan lancar tanpa terdapat kesalahan dan mengecek kembali aplikasi recovery file (Wondershare Dr. Fone for Android) dan database browser (SQLite Manager dan DB Browser for SQLite) telah sesuai dengan ketentuan pada conceptual model, input output data, dan modelling.

\section{II.7 Experimentation}

Setelah proses root pada smartphone berhasil dilakukan tanpa ada kesalahan dan aplikasi recovery file (Wondershare Dr. Fone for Android) dan database browser (SQLite Manager dan DB Browser for SQLite) telah terpasang, maka akan dilakukan proses simulasi pencarian bukti forensik pada aplikasi media sosial yang diakses menggunakan smartphone berbasis Android sesuai dengan konsep, model dan flowchart simulasi yang telah dijelaskan sebelumnya. Setelah proses pencarian bukti forensik selesai, maka akan dilakukan analisa terhadap bukti-bukti forensik tersebut.

\section{II.8 Output Analysis}

Analisa hasil yang didapat setelah selesai menjalankan semua skenario yang akan dibahas pada bab selanjutnya.

\section{III.HASIL DAN PEMBAHASAN}

\section{III.1 Simulasi 1}

Pada skenario 1 simulasi dilakukan untuk mengembalikan file dan data-data aplikasi media sosial yang sebelumnya telah dihapus pada smartphone.

Berikut adalah hasil simulasi skenario:
Tabel 2. Hasil Perbandingan Skenario 1

\begin{tabular}{lll}
\hline Skenario 1 & \multicolumn{1}{c}{ Facebook } & \multicolumn{1}{c}{ Twitter } \\
\hline $\begin{array}{l}\text { Mengembal } \\
\text { ikan file } \\
\text { dan data- } \\
\text { data yang } \\
\text { dihapus }\end{array}$ & $\begin{array}{l}\text { File dan data- } \\
\text { data berhasil } \\
\text { dikembalikan }\end{array}$ & $\begin{array}{l}\text { File dan data- } \\
\text { data berhasil } \\
\text { dikembalikan }\end{array}$ \\
\hline $\begin{array}{l}\text { Data dan } \\
\text { file yang }\end{array}$ & com.facebook. & com.twitter.an \\
dikembalik & katana (file dan & droid (file dan \\
an & Fata-data & data-data \\
& Apps) & Twitter Apps) \\
& com.facebook. & \\
& orca (file dan & \\
& data-data & \\
& Facebook & \\
& Messenger) & \\
\hline
\end{tabular}

Pada tabel 2 dapat dilihat hasil skenario 1, data-data pada aplikasi media sosial Facebook dan Twitter yang sebelumnya telah dihapus telah berhasil dikembalikan. Pada aplikasi media sosial Facebook, data yang berhasil dikembalikan adalah file com.facebook.katana (file dan data-data Facebook Apps) dan file com.facebook.orca (file dan data-data Facebook Messenger).

Sedangkan pada aplikasi media sosial Twitter, data yang berhasil dikembalikan adalah file com.twitter.android (file dan datadata Twitter Apps).

\section{III.2 Simulasi 2}

Pada skenario 2 simulasi dilakukan untuk menemukan bukti forensik berupa nama akun dari pengguna aplikasi media sosial Facebook dan Twitter pada smartphone Android menggunakan SQLite Manager dan DB Browser for SQLite. Berikut adalah hasil simulasi skenario:

Tabel 3. Hasil Perbandingan Skenario 2

\begin{tabular}{|c|c|c|}
\hline Skenario 2 & Facebook & Twitter \\
\hline $\begin{array}{l}\text { Menemukan } \\
\text { bukti } \\
\text { forensik } \\
\text { berupa nama } \\
\text { akun }\end{array}$ & $\begin{array}{l}\text { Nama } \\
\text { akun } \\
\text { berhasil } \\
\text { ditemukan }\end{array}$ & $\begin{array}{l}\text { Nama akun } \\
\text { berhasil } \\
\text { ditemukan }\end{array}$ \\
\hline $\begin{array}{l}\text { Bukti } \\
\text { forensik } \\
\text { yang } \\
\text { ditemukan }\end{array}$ & $\begin{array}{l}\text { Nama } \\
\text { akun: } \\
\text { Pratama } \\
\text { Pertama } \\
\end{array}$ & $\begin{array}{l}\text { Nama akun: } \\
\text { Pratama Pertama } \\
\text { (@Pratama1_satu) }\end{array}$ \\
\hline
\end{tabular}


Pada tabel 3 dapat dilihat hasil skenario 2, pada aplikasi media sosial Facebook, bukti forensik berupa nama akun berhasil ditemukan. Bukti forensik ditemukan pada file database contact_db2, pada tabel contacts.

Kemudian pada aplikasi media sosial Twitter, bukti forensik berupa nama akun juga berhasil ditemukan. Bukti forensik ditemukan pada file database 732798704059621380-43, pada tabel users.

\section{III.3 Simulasi 3}

Pada skenario 3 simulasi dilakukan untuk menemukan bukti forensik berupa data lokasi dari pengguna aplikasi media sosial Facebook dan Twitter pada smartphone Android menggunakan SQLite Manager dan DB Browser for SQLite. Berikut adalah hasil simulasi skenario:

Tabel 4. Hasil Perbandingan Skenario 3

\begin{tabular}{lll}
\hline \multicolumn{1}{c}{ Skenario 3 } & \multicolumn{1}{c}{ Facebook } & \multicolumn{1}{c}{ Twitter } \\
\hline Menemukan & Data lokasi & Data lokasi \\
bukti forensik & berhasil & tidak berhasil \\
berupa lokasi & ditemukan & ditemukan \\
\hline Bukti forensik & Data lokasi: & Data lokasi: \\
yang & Semarang, & Semarang, \\
ditemukan & Indonesia & Indonesia \\
\hline
\end{tabular}

Pada tabel 4 dapat dilihat hasil skenario 3, pada aplikasi media sosial Facebook, bukti forensik berupa data lokasi berhasil ditemukan. Bukti forensik ditemukan pada file database contact_db2, pada tabel contacts, dan pada kolom data.

Kemudian pada aplikasi media sosial Twitter, bukti forensik berupa data lokasi akun juga berhasil ditemukan. Bukti forensik ditemukan pada file database 732798704059621380-43, pada tabel users.

\section{III.4 Simulasi 4}

Pada skenario 4 simulasi dilakukan untuk menemukan bukti forensik berupa data nomor telepon dari pengguna aplikasi media sosial Facebook dan Twitter pada smartphone Android menggunakan SQLite Manager dan DB Browser for SQLite. Berikut adalah hasil simulasi skenario:

Tabel 5. Hasil Perbandingan Skenario 4

\begin{tabular}{lll}
\hline Skenario 4 & \multicolumn{1}{c}{ Facebook } & \multicolumn{1}{c}{ Twitter } \\
\hline Menemukan & Nomor Telepon & Nomor \\
bukti & berhasil & Telepon \\
forensik & ditemukan & tidak \\
\hline
\end{tabular}

\begin{tabular}{lll}
\hline $\begin{array}{l}\text { berupa } \\
\text { nomor } \\
\text { telepon }\end{array}$ & & $\begin{array}{l}\text { berhasil } \\
\text { ditemukan }\end{array}$ \\
\hline Bukti \\
forensik & Nomor telepon: & Tidak ada \\
yang & +6285776267290 & Asumsi \\
ditemukan & & data tidak \\
& & ditemukan: \\
& data tidak \\
& & tersimpan \\
& pada \\
& & database \\
& & melainkan \\
& & pada \\
& & server. \\
\hline
\end{tabular}

Pada tabel 5 dapat dilihat hasil skenario 4, pada aplikasi media sosial Facebook, bukti forensik berupa nomor telepon pada berhasil ditemukan. Bukti forensik ditemukan pada file database contact_db2, pada tabel contacts, dan pada kolom data.

Sedangkan pada aplikasi media sosial Twitter, bukti forensik berupa nomor telepon pada akun tidak berhasil ditemukan. Penulis berasumsi bahwa bukti forensik yang tidak berhasil ditemukan tersebut disebabkan karena data tersebut tidak disimpan pada database melainkan pada server.

\section{III.5 Simulasi 5}

Pada skenario 5 simulasi dilakukan untuk menemukan bukti forensik berupa data tanggal lahir dari pengguna aplikasi media sosial Facebook dan Twitter pada smartphone Android menggunakan SQLite Manager dan DB Browser for SQLite. Berikut adalah hasil simulasi skenario:

Tabel 6. Hasil Perbandingan Skenario 5

\begin{tabular}{|c|c|c|}
\hline Skenario 5 & Facebook & Twitter \\
\hline $\begin{array}{l}\text { Menemukan } \\
\text { bukti forensik } \\
\text { berupa } \\
\text { tanggal lahir }\end{array}$ & $\begin{array}{l}\text { Tanggal lahir } \\
\text { berhasil } \\
\text { ditemukan }\end{array}$ & $\begin{array}{l}\text { Tanggal lahir } \\
\text { tidak berhasil } \\
\text { ditemukan }\end{array}$ \\
\hline $\begin{array}{l}\text { Bukti forensik } \\
\text { yang } \\
\text { ditemukan }\end{array}$ & $\begin{array}{l}\text { Tanggal lahir: } \\
1 \text { Januari }\end{array}$ & $\begin{array}{l}\text { Tidak ada } \\
\text { Asumsi data } \\
\text { tidak } \\
\text { ditemukan: } \\
\text { data tidak } \\
\text { tersimpan } \\
\text { pada } \\
\text { database } \\
\text { melainkan } \\
\text { pada server }\end{array}$ \\
\hline
\end{tabular}


Pada Tabel 6 dapat dilihat hasil skenario 5, pada aplikasi media sosial Facebook, bukti forensik berupa data tanggal lahir akun berhasil ditemukan. Bukti forensik ditemukan pada file database contact_db2, pada tabel contacts.

Sedangkan, pada aplikasi media sosial Twitter, bukti forensik berupa tanggal lahir akun tidak berhasil ditemukan. Penulis berasumsi bahwa bukti forensik yang tidak berhasil ditemukan tersebut disebabkan karena data tersebut tidak disimpan pada database melainkan pada server.

\section{III.6 Simulasi 6}

Pada skenario 6 simulasi dilakukan untuk menemukan bukti forensik berupa profile picture dari pengguna aplikasi media sosial Facebook dan Twitter pada smartphone Android menggunakan SQLite Manager dan DB Browser for SQLite. Berikut adalah hasil simulasi skenario:

Tabel 7. Hasil Perbandingan Skenario 6

\begin{tabular}{|c|c|c|}
\hline $\begin{array}{c}\text { Skenario } \\
6\end{array}$ & Facebook & Twitter \\
\hline $\begin{array}{l}\text { Menemu } \\
\text { kan bukti } \\
\text { forensik } \\
\text { berupa } \\
\text { Profile } \\
\text { Picture }\end{array}$ & $\begin{array}{l}\text { Profile Picture } \\
\text { berhasil } \\
\text { ditemukan }\end{array}$ & $\begin{array}{l}\text { Profile Picture } \\
\text { berhasil } \\
\text { ditemukan }\end{array}$ \\
\hline $\begin{array}{l}\text { Bukti } \\
\text { forensik } \\
\text { yang } \\
\text { ditemuka } \\
\text { n }\end{array}$ & $\begin{array}{l}\text { url yang } \\
\text { mengarahkan } \\
\text { pada Profile } \\
\text { Picture akun } \\
\text { tersebut: } \\
\text { https://sconten } \\
\text { t-sit4- } \\
\text { 1.xx.fbcdn.net/ } \\
\text { v/t1.0- } \\
\text { 1/p160x160/15 } \\
284946 \_24557 \\
7259194628 \_5 \\
240603142837 \\
268906 \_n . j p g ? \\
\text { efg=eyJkdHci } \\
\text { OiIifQ\%3D\%3 } \\
\text { D\&_nc_ad=z- } \\
\text { m\&oh=f06ecf } \\
4 a 770 d 703 d 9 d \\
9874 f b 09 f 59 b e \\
2 \& o e=58 F 4 B \\
\text { A26 }\end{array}$ & $\begin{array}{l}\text { url yang } \\
\text { mengarahkan } \\
\text { pada Profile } \\
\text { Picture akun } \\
\text { tersebut: } \\
\text { https://pbs.twim } \\
\text { g.com/profile_i } \\
\text { mages/7966871 } \\
\text { 30806235141/R } \\
\text { pdUQBRF_nor } \\
\text { mal.jpg }\end{array}$ \\
\hline
\end{tabular}

Pada Tabel 7 dapat dilihat hasil skenario 6, pada aplikasi media sosial Facebook, bukti forensik berupa profil picture akun berhasil ditemukan. Bukti forensik ditemukan pada file database contact_db2, pada tabel contacts.

Kemudian pada aplikasi media sosial Twitter, bukti forensik berupa profil picture akun juga berhasil ditemukan. Bukti forensik ditemukan pada pada file database 732798704059621380-43, pada tabel users.

\section{III.7 Simulasi 7}

Pada skenario 7 simulasi dilakukan untuk menemukan bukti forensik berupa cover photo dari pengguna aplikasi media sosial Facebook dan Twitter pada smartphone Android menggunakan SQLite Manager dan DB Browser for SQLite. Berikut adalah hasil simulasi skenario: 
Tabel 8. Hasil Perbandingan Skenario 7

\begin{tabular}{|c|c|c|}
\hline $\begin{array}{c}\text { Skenario } \\
7\end{array}$ & Facebook & Twitter \\
\hline $\begin{array}{l}\text { Menemuk } \\
\text { an bukti } \\
\text { forensik } \\
\text { berupa } \\
\text { Cover } \\
\text { Photo }\end{array}$ & $\begin{array}{l}\text { Cover Photo } \\
\text { berhasil ditemukan }\end{array}$ & $\begin{array}{l}\text { Cover } \\
\text { Photo } \\
\text { berhasil } \\
\text { ditemuka } \\
\mathrm{n}\end{array}$ \\
\hline $\begin{array}{l}\text { Bukti } \\
\text { forensik } \\
\text { yang } \\
\text { ditemuka } \\
\text { n }\end{array}$ & 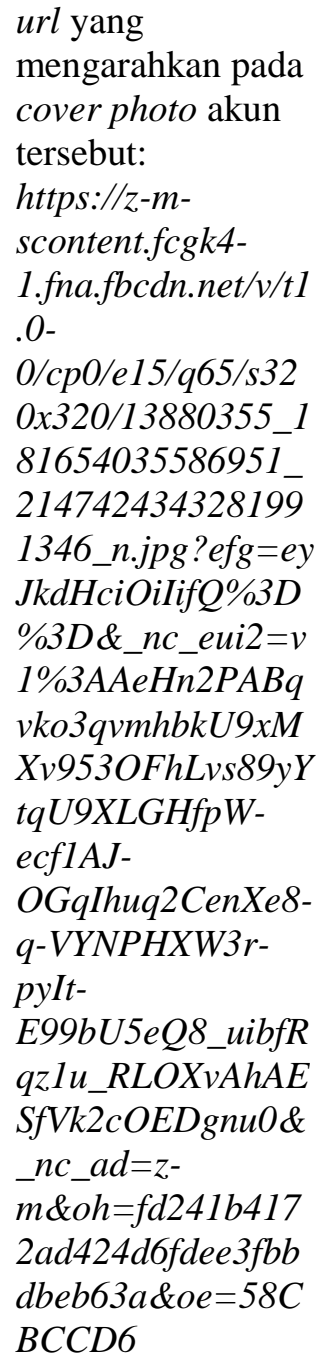 & $\begin{array}{l}\text { url yang } \\
\text { mengarah } \\
\text { kan pada } \\
\text { cover } \\
\text { photo } \\
\text { akun } \\
\text { tersebut: } \\
\text { https://pb } \\
\text { s.twimg.c } \\
\text { om/profil } \\
\text { e_banner } \\
\text { s/732798 } \\
70405962 \\
1380 / 148 \\
0930200\end{array}$ \\
\hline
\end{tabular}

Pada tabel 8 dapat dilihat hasil skenario 7 , pada aplikasi media sosial Facebook, bukti forensik berupa cover photo berhasil ditemukan. Bukti forensik ditemukan pada file database contact_db2, pada tabel contacts, dan pada kolom data.

Kemudian pada aplikasi media sosial Twitter, bukti forensik berupa cover photo pada akun juga berhasil ditemukan. Bukti forensik ditemukan pada file database 732798704059621380-43, pada tabel users.

\section{III.8 Simulasi 8}

Pada skenario 8 simulasi dilakukan untuk menemukan bukti forensik berupa posting atau tweet (bentuk teks) dari pengguna aplikasi media sosial Facebook dan Twitter pada smartphone Android menggunakan SQLite Manager dan DB Browser for SQLite. Berikut adalah hasil simulasi skenario:

Tabel 9. Hasil Perbandingan Skenario 8

\begin{tabular}{|c|c|c|}
\hline Skenario 8 & Facebook & Twitter \\
\hline $\begin{array}{l}\text { Menemukan } \\
\text { bukti forensik } \\
\text { berupa } \\
\text { posting atau } \\
\text { tweet (bentuk } \\
\text { teks) }\end{array}$ & $\begin{array}{l}\text { Posting } \\
\text { berhasil } \\
\text { ditemukan }\end{array}$ & $\begin{array}{l}\text { Twitter } \\
\text { berhasil } \\
\text { ditemukan }\end{array}$ \\
\hline $\begin{array}{l}\text { Bukti } \\
\text { forensik yang } \\
\text { ditemukan }\end{array}$ & $\begin{array}{l}\text { Isi posting } \\
\text { bertuliskan: } \\
\text { Test } 123 \text { dan } \\
\text { url yang } \\
\text { mengarahkan } \\
\text { kepada posting } \\
\text { terkait: } \\
\text { https://m.facebo } \\
\text { ok.com/story.ph } \\
\text { p?story_fbid=2 } \\
\text { 3575929684309 } \\
\text { 1\&id=1000122 } \\
70664021 M j M 1 \\
\text { NzUSMjk2ODQ } \\
\text { zMDkxOjU6MA } \\
==0 U z p f S T E w \\
\text { MDAxMjI3MD } \\
Y 2 N D A y M T o y \\
\text { MzU3NTkyOTY } \\
4 N D M w O T E=\end{array}$ & $\begin{array}{l}\text { Isi posting } \\
\text { bertuliskan } \\
\text { : Test } 123\end{array}$ \\
\hline
\end{tabular}

Pada tabel IX dapat dilihat hasil skenario 8, pada aplikasi media sosial Facebook, bukti forensik berupa posting (bentuk teks) pada akun berhasil ditemukan. Bukti forensik ditemukan pada file top_stories_1479273092981. Bukti tersebut ditemukan setelah melakukan pencarian pada database newsfeed_db. Pada database tersebut ditemukan tabel berisi alamat tempat file disimpan. Setelah file top_stories_1479273092981 dibuka dengan menggunakan aplikasi Notepad, ditemukan isi posting beserta url posting tersebut.

Kemudian pada aplikasi media sosial Twitter, bukti forensik berupa tweet (bentuk teks) pada akun juga berhasil ditemukan. Bukti forensik ditemukan pada pada file database 
732798704059621380-43, pada tabel full_content.

\section{III.9 Simulasi 9}

Pada skenario 9 simulasi dilakukan untuk menemukan bukti forensik berupa posting atau tweet (bentuk gambar) dari pengguna aplikasi media sosial Facebook dan Twitter pada smartphone Android menggunakan SQLite Manager dan DB Browser for SQLite. Berikut adalah hasil simulasi skenario:

Tabel 10. Hasil Perbandingan Skenario 9

\begin{tabular}{|c|c|c|}
\hline Skenario 9 & Facebook & Twitter \\
\hline $\begin{array}{l}\text { Menemukan } \\
\text { bukti } \\
\text { forensik } \\
\text { berupa } \\
\text { posting atau } \\
\text { tweet } \\
\text { (bentuk } \\
\text { gambar) }\end{array}$ & $\begin{array}{l}\text { Posting berhasil } \\
\text { ditemukan }\end{array}$ & $\begin{array}{l}\text { Tweet } \\
\text { berhasil } \\
\text { ditemuk } \\
\text { an }\end{array}$ \\
\hline $\begin{array}{l}\text { Bukti } \\
\text { forensik } \\
\text { yang } \\
\text { ditemukan }\end{array}$ & $\begin{array}{l}\text { Isi posting } \\
\text { bertuliskan: Dijual } \\
\text { hp Nokia } 3310 \\
\text { kondisi baru. } \\
\text { Harga Rp2.000.000 } \\
\text { Garansi Distributor } \\
1 \text { tahun. } \\
\text { Harga bisa nego. } \\
\text { dan url yang } \\
\text { mengarahkan kepada } \\
\text { gambar terkait: } \\
\text { https://scontent- } \\
\text { sin6- } \\
\text { 1.xx.fbcdn.net/t31.0- } \\
\text { 8/cp0/e15/q65/s720x } \\
\text { 720/14361331_2055 } \\
\text { 79889861032_4072 } \\
\text { 761814445104575_ } \\
\text { o.jpg?_nc_ad=z-m }\end{array}$ & $\begin{array}{l}\text { Isi } \\
\text { posting } \\
\text { bertulisk } \\
\text { an: } \\
\text { Dijual } \\
\text { hp } \\
\text { Nokia } \\
3310 \\
\text { kondisi } \\
\text { baru. } \\
\text { Harga } \\
\text { Rp2.000 } \\
.000 \\
\text { Garansi } \\
\text { Distribu } \\
\text { tor } 1 \\
\text { tahun. } \\
\text { Harga } \\
\text { bisa } \\
\text { nego. } \\
\text { dan } u r l \\
\text { yang } \\
\text { mengara } \\
\text { hkan } \\
\text { kepada } \\
\text { gambar } \\
\text { terkait: } \\
\text { pic.twitt } \\
\text { er.com/ } \\
\text { mfOfdeP } \\
\text { yDE }\end{array}$ \\
\hline
\end{tabular}

Pada tabel 10 dapat dilihat hasil skenario 9, pada aplikasi media sosial Facebook, bukti forensik berupa posting (berupa gambar) pada akun berhasil ditemukan. Bukti forensik ditemukan pada file top_stories_1474368104704. Bukti tersebut ditemukan setelah melakukan pencarian pada database newsfeed_db. Pada database tersebut ditemukan tabel berisi alamat tempat file disimpan. Setelah file top_stories_1474368104704 dibuka dengan menggunakan aplikasi Notepad, ditemukan $U R L$ yang mengarahkan pada gambar tersebut. Bila URL tersebut dibuka dengan menggunakan browser maka akan menampilkan gambar yang dimaksud.

Kemudian pada aplikasi media sosial Twitter, bukti forensik berupa tweet (berupa gambar) pada akun juga berhasil ditemukan. Bukti forensik ditemukan pada file database 732798704059621380-43, pada tabel statuses. Pada gambar terlihat bukti yang ditemukan berupa $U R L$. Bila $U R L$ tersebut dibuka dengan menggunakan browser maka akan menampilkan gambar yang dimaksud.

\section{III.10 Simulasi 10}

Pada skenario 10 simulasi dilakukan untuk menemukan bukti forensik berupa private message atau direct message (bentuk teks) dari pengguna aplikasi media sosial Facebook dan Twitter pada smartphone Android menggunakan SQLite Manager dan DB Browser for SQLite. Berikut adalah hasil simulasi skenario:

Tabel 11. Hasil Perbandingan Skenario 10

\begin{tabular}{|c|c|c|}
\hline Skenario 10 & Facebook & Twitter \\
\hline $\begin{array}{l}\text { Menemukan } \\
\text { bukti } \\
\text { forensik } \\
\text { berupa } \\
\text { private } \\
\text { message } \\
\text { atau direct } \\
\text { message } \\
\text { (bentuk } \\
\text { teks) }\end{array}$ & $\begin{array}{l}\text { Private } \\
\text { message } \\
\text { (bentuk teks) } \\
\text { berhasil } \\
\text { ditemukan }\end{array}$ & $\begin{array}{l}\text { Direct message } \\
\text { (bentuk teks) } \\
\text { tidak berhasil } \\
\text { ditemukan }\end{array}$ \\
\hline $\begin{array}{l}\text { Bukti } \\
\text { forensik } \\
\text { yang } \\
\text { ditemukan }\end{array}$ & $\begin{array}{l}\text { Isi percakaan } \\
\text { Duo kedua: } \\
\text { Halo pak } \\
\text { pratama } \\
\text { Pratama } \\
\text { pertama: ya? } \\
\text { Duo kedua: } \\
\text { Apa harga hp } \\
\text { tersebut bisa } \\
\text { kurang lagi }\end{array}$ & $\begin{array}{l}\text { Tidak } \\
\text { ditemukan } \\
\text { Asumsi data } \\
\text { tidak } \\
\text { ditemukan: } \\
\text { data tidak } \\
\text { tersimpan pada } \\
\text { database } \\
\text { melainkan } \\
\text { pada server }\end{array}$ \\
\hline
\end{tabular}

Wisnu, dkk: Analisa dan Perbandingan ... 


\begin{tabular}{ll}
\hline jadi $1,8 \mathrm{jt} ?$ \\
Pratama \\
pertama: \\
Tentu bisa $\odot$ \\
Dan \\
seterusnya \\
\hline
\end{tabular}

Pada Tabel 11 dapat dilihat hasil skenario 10, pada aplikasi media sosial Facebook, bukti forensik berupa private message (bentuk teks) pada akun berhasil ditemukan. Bukti forensik ditemukan pada file database threads_db2, pada tabel messages. Seluruh isi percakapan terdapat pada kolom text.

Sedangkan pada aplikasi media sosial Twitter, bukti forensik berupa direct message (bentuk teks) pada akun tidak berhasil ditemukan. Penulis berasumsi bahwa bukti forensik yang tidak berhasil ditemukan tersebut disebabkan karena data tersebut tidak disimpan pada database melainkan pada server.

\section{III.11 Simulasi 11}

Pada skenario 11 simulasi dilakukan untuk menemukan bukti forensik berupa private message atau direct message (bentuk gambar) dari pengguna aplikasi media sosial Facebook dan Twitter pada smartphone Android menggunakan SQLite Manager dan DB Browser for SQLite. Berikut adalah hasil simulasi skenario:

Tabel 12. Hasil Perbandingan Skenario 11

\begin{tabular}{|c|c|c|}
\hline $\begin{array}{c}\text { Skenario } \\
11\end{array}$ & Facebook & Twitter \\
\hline $\begin{array}{l}\text { Menemuk } \\
\text { an bukti } \\
\text { forensik } \\
\text { berupa } \\
\text { private } \\
\text { message } \\
\text { atau direct } \\
\text { message } \\
\text { (bentuk } \\
\text { gambar) }\end{array}$ & $\begin{array}{l}\text { Private message } \\
\text { (bentuk gambar) } \\
\text { berhasil } \\
\text { ditemukan }\end{array}$ & $\begin{array}{l}\text { Direct } \\
\text { message } \\
\text { (bentuk } \\
\text { gambar) } \\
\text { tidak } \\
\text { berhasil } \\
\text { ditemukan }\end{array}$ \\
\hline $\begin{array}{l}\text { Bukti } \\
\text { forensik } \\
\text { yang } \\
\text { ditemukan }\end{array}$ & $\begin{array}{l}\text { url yang } \\
\text { mengarahkan } \\
\text { kepada gambar } \\
\text { terkait: } \\
\text { https://scontent.x } \\
\text { x.fbcdn.net/v/t34. } \\
\text { O- } \\
\text { 12/fr/cp0/e15/q65 } \\
\text { /14389696_20492 } \\
\text { 1393260315_210 }\end{array}$ & $\begin{array}{l}\text { Tidak } \\
\text { ditemukan } \\
\text { Asumsi data } \\
\text { tidak } \\
\text { ditemukan: } \\
\text { data tidak } \\
\text { tersimpan } \\
\text { pada } \\
\text { database } \\
\text { melainkan } \\
\end{array}$ \\
\hline
\end{tabular}

Wisnu, dkk: Analisa dan Perbandingan ...

6835510_n.jpg?_ pada server
nc_ad=z-
$m \& o h=15$ daObal
bc784b6dce926b
$988 d b 10 e 73 \& o e$
$=57 E 3 C 350$

Pada Tabel 12 dapat dilihat hasil skenario 11, pada aplikasi media sosial Facebook, bukti forensik berupa private message (bentuk gambar) pada akun berhasil ditemukan. Bukti forensik ditemukan pada file database threads_db2, pada tabel messages. Bukti forensik yang ditemukan berupa url. Bila url tersebut disalin dan dibuka pada browser maka akan menampilkan gambar tersebut.

Sedangkan pada aplikasi media sosial Twitter, bukti forensik berupa direct message (bentuk gambar) pada akun tidak berhasil ditemukan. Penulis berasumsi bahwa bukti forensik yang tidak berhasil ditemukan tersebut disebabkan karena data tersebut tidak disimpan pada database melainkan pada server.

\section{PENUTUP}

Berdasarkan hasil dari tahapan-tahapan metode simulasi yang telah dilakukan, proses pencarian dan analisa bukti forensik pada aplikasi media sosial Facebook dan Twitter yang diakses pada smartphone Android dapat disimpulkan bahwa data-data pada media sosial Facebook dan Twitter tidak sepenuhnya disimpan pada server. Data tersebut juga tersimpan pada memori internal perangkat Android yang hanya dapat diakses setelah perangkat Android melalui proses root.

Berdasarkan tabel hasil semua skenario pencarian bukti forensik yang telah ditentukan sebelumnya, pada aplikasi media sosial Facebook semua bukti forensik dapat ditemukan. Bukti forensik yang ditemukan adalah nama akun, data lokasi, nomor telepon, tanggal lahir, photo profile, cover photo, posting berupa teks, posting berupa gambar, private message berupa teks dan private message berupa gambar.

Pada aplikasi media sosial Twitter bukti forensik yang ditemukan hanya nama akun, data lokasi, photo profile, cover photo, tweet (posting) berupa teks dan tweet (posting) berupa gambar. Sedangkan bukti forensik berupa nomor telepon, tanggal lahir, direct message berupa teks dan direct message 
berupa gambar tidak ditemukan. Tidak ada perbedaan hasil pencarian bukti forensik dengan menggunakan aplikasi SQLite Manager maupun DB Browser for SQLite.

Berdasarkan pemaparan tersebut dapat disimpulkan bahwa bukti forensik lebih banyak ditemukan pada media sosial Facebook dan tidak ada perbedaan hasil pencarian bukti forensik dengan menggunakan aplikasi SQLite Manager maupun DB Browser for SQLite.

\section{DAFTAR PUSTAKA}

[1] Beek, C. (2011). Introduction to File Carving. McAfee.

[2] Devita, \& Amal, N. N. (2014). Media Sosial dan Perkembangan Fashion Hijab. Jurnal Komunikasi.

[3] Guardian, T. (2012, Desember 27). Social media related crime reports up $780 \%$ in four years. Retrieved from The Guardian:

https://www.theguardian.com/media/201 2/dec/27/social-media-crime-facebooktwitter

[4] Indrajit, R. E. (2012). Forensik Komputer. Forensik Komputer.

[5] Jansen, W., \& Ayers, R. (2007). Guidelines on Cell Phone Forensics. Gaithersburg: National Institute of Standards and Technology.

[6] Kemp, S. (2016, Januari 27). Digital in 2016. Retrieved from We Are Social Website:

http://wearesocial.com/uk/specialreports/digital-in-2016

[7] Lazierthanthou. (2016, 10 1). Mozilla Foundation. Retrieved from Mozilla Foundation Website: https://addons.mozilla.org/id/firefox/add on/sqlite-manager/

[8] Madani, S. A., J. K., \& Mahlkneccht, S. (2010). Wireless sensor networks: modeling and simulation.

[9] Mathur, A., Schlotfeldt, B., \& Chetty, M. (2015). A mixed-methods study of mobile users' data usage practices in South Africa. Proceedings of the 2015 ACM International Joint Conference on Pervasive and Ubiquitous Computing, 1209-1220.

[10] Merola, A. (2008). Data Carving Concept. Data Carving.

[11] Möller, A., Kranz, M., Schmid, B., Roalter, L., \& Diewald, S. (2013).
Investigating self-reporting behavior in long-term studies. Proceedings of the SIGCHI Conference on Human Factors in Computing Systems, 2931-2940.

[12] Mutawa, N. A., Baggili, \& Marrington. (2012). Forensic analysis of social networking applications on mobile devices. Digital Investigation.

[13] Nugroho, D. R., Suadi, W., \& Pratomo, B. A. (2010). Implementasi Sistem Manajemen Database untuk SQLite di Sistem Android. Android Database SQLite.

[14] Raharjo, B. (2013). Sekilas Mengenai Forensik Digital.

[15] Safaat, N. (2012). Pemrograman Aplikasi Mobile Smartphone. Bandung: Informatika.

[16] Setyani, \& Ika, N. (2013). Penggunaan Media Sosial Sebagai Sarana Bagi Komunitas. Jurnal Komunikasi.

[17] Smith, E. (2013, Agustus 21). Crime Wire: Social Media and Crime. Retrieved from Instant Checkmate: https://www.instantcheckmate.com/crim ewire/2013/08/21/social-media-andcrime-2/

[18] Staff, A. (2012, Juli 18). Social Media's Role In Law Enforcement Growing. Retrieved from Breaking Gov Website: http://breakinggov.com/2012/07/18/soci al-medias-role-in-law-enforcementgrowing/

[19] Walniyccky, D., Baggili, I., Marrington, A., Moore, J., \& Breitinger, F. (2015). Network and device forensic analysis of Android. Digital Investigation.

[20] Wiliams, B. K., \& Sawyer, S. C. (2011). Using Information Technology: A Practical Introduction to Computers \& Communications. (9th edition). New York: McGraw-Hill.

[21] Wilson, C. (2015, September 15). Android Phone Forensic Analysis. Retrieved from Data Forensic: http://www.dataforensics.org/androidphone-forensics-analysis/

[22] Yadi, I. Z., \& Kunang, Y. N. (2014). Analisis Forensik pada Platform Android. Konferensi Nasional Ilmu Komputer (KONIK) 2014.

[23] Yusoff, M., Dehghantanha, A., \& Mahmod, R. (2016). Forensic Investigation of Social Media and Instant Messaging Services in Firefox 
OS: Facebook, Twitter, Google+, Telegram, OpenWapp and Line as Case Studies. Forensic.

[24] Felix Richter (2016). Facebook Inc. Dominates the Social Media Landscape: https://www.statista.com/chart/5194/acti ve-users-of-social-networks-andmessaging-services/ 